\title{
"Modern Prophets, Produce a New Bible": Christianity, Africanness and the Poetry of Nontsizi Mgqwetho
}

\author{
Duncan Brown
}

\begin{abstract}
In this article I consider how one might approach the apparently singular figure of Nontsizi Mgqwetho, a Xhosa woman who produced an extraordinary series of Christian izibongo in newspapers in the 1920s: through what kind of language, from what critical perspective, might one think and write about her? There have been various attempts to write about Mgqwetho, and there are certain obvious possibilities in terms of approach and methodology, which I explore briefly, but I want to suggest a mode of reading which provides a richer, more engaged and more engaging understanding - one which reads with and through, rather than onto or against, her African Christian articulations.
\end{abstract}

In her perceptive review article on women saints, Hilary Mantel poses the question of one of them, Gemma Galgani: "When you look at her strange life, you wonder what kind of language you can use to talk about her through which discipline will you approach her?” (2004:14). ${ }^{1}$ Taking up Mantel's challenge, in this article I consider how one might approach the apparently singular figure of Nontsizi Mgqwetho, a Xhosa woman who produced an extraordinary series of Christian izibongo in newspapers in the 1920s: through what kind of language, from what critical perspective, might one think and write about her; how does one understand her, account for her, give account of her? There have been various attempts to write about Mgqwetho, including my own, and there are certain obvious possibilities in terms of approach and methodology, which I will explore briefly, but I want to suggest a mode of reading which I think provides a richer, more engaged and more engaging understanding - one which reads 
with and through, rather than onto or against, her African Christian articulations.

Nontsizi Mgqwetho was a Xhosa poet who published between 1920 and 1929 in the newspaper Umteteli wa Bantu (The People's Spokesman). She is one of the first black woman poets to have produced a substantial body of work: 95 poems and three articles appeared between 23 October 1920 and 4 September 1926; and two more poems appeared after a two-year gap on 22 December 1928 and 5 January 1929. Jeff Opland and I have been the only critics to write on $\mathrm{Mgqwetho}^{2}$ (besides a brief discussion by Deborah Gaitskell in an article on women's prayer groups (1997), and even briefer mentions in Hofmeyr (2004) and Daymond et al (2003)). Her work was discovered by Opland in its archival locations, and edited and translated by him (with assistance from Phyllis Ntantala and Abner Nyamende) in the recently-published volume The Nation's Bounty: The Xhosa Poetry of Nontsizi Mgqwetho (2007). ${ }^{3}$ Something of the concerns of her work is suggested in an early poem:

Mercy, woman poet, wing of Africa.

Make way! Ach, I was used.

Mercy, starling perched in a fig tree, your poems dispense with feminine wiles.

Mercy, Nontsizi, African moss, let old maids screen their bodies in bodices for no one knows your ancestors: without skin skirts there'll be no weddings.

Where are your daughters? What do you say?

"We roamed the countryside searching for marriage, we turned our backs on home and dowry, today we're exploited in exile homes.”

What's education? Where are your sons?

They roamed the land in search of niks, chickens scratching for scraps, eager at dawn, at dusk empty-handed.

Mercy, Nontsizi, striped gold-breasted bunting that piped its prophecies through the thornbrakes; Awu! Mercy, poetic diviner, watch out, the wild bird's flapping its wings.

(Opland 2007: 78) ${ }^{4}$ 
What little we know of Mgqwetho's life is based largely on her writings. ${ }^{5}$ In a poem about the death of her mother, published on 2 December 1922, she gives her mother's name as Emmah Jane Mgqwetto, daughter of Zingelwa of the Cwerha clan, and associates her with the Hewu district near Queenstown. Abner Nyamende, who discussed the translation of some of the poems with Opland, claims that there are Moravian liturgical influences in her poetry, which may suggest that she was educated in the Eastern Cape by the Moravians, probably at Shiloh which is in the Hewu district (Opland 1998: 333), though as I shall suggest, there are stronger African Methodist Episcopalian (AME) influences in her life and work. She seems to have lived at Peddie (the site of an AME church), possibly at Tamara, as she is according to Opland - the likely author of two prose contributions to the King William's Town newspaper Imvo zabaNtsundu (African Opinion) on 20 May and 14 October 1897, both signed with her clan name Cizama, and the latter coming from Tamara. In a poem that appeared in Umteteli wa Bantu on 18 December 1920 she criticises LT Mvabaza, editor of the newspaper Abantu-Batho (People), for bragging that he had brought her from Peddie to Johannesburg. Her first poem in Umteteli wa Bantu, published on 23 October 1920, was signed with her clan name Cizama, and sent from Crown Mines in Johannesburg. From a reference to herself in a poem ("ungainly girl with ill-shaped frame./ Awu Nontsizi, African moss,/ with bow-legs like yours you'll never marry!” (78)) it seems she may have been unmarried, although the hyperbolic and intertextual nature of Xhosa personal praises means that such references may not be literally 'true'. Her poems suggest that she was socially and politically active, though critical of the ANC for what she perceived to be its role in dividing black opposition. She defended and promoted the first editor of Umteteli wa Bantu, Marshall Maxeke, and his wife, civil rights activist Charlotte Maxeke; appears to have been arrested for political activity ("I blundered in going to whites:/ Oh I felt the cops' cuffs on me!” (78)); and took part in the April 1919 demonstration against passes in Johannesburg (referred to in a prose contribution published on 13 December 1924). She was a firm supporter and probably a member of a women's prayer group, and also active in the temperance movement.

$$
* * *
$$

One can approach the work of Nontsizi Mgqwetho in a variety of ways. Opland's concern is to situate her within a Xhosa literary and social history, which his own substantial scholarship has helped to unearth. He says: "the poetry she left immediately claims for her the status of one of the 
greatest literary artists ever to write in Xhosa, an anguished voice of an urban woman confronting male dominance, ineffective leadership, black apathy, white malice and indifference, economic exploitation and a tragic history of nineteenth-century territorial and cultural dispossession" (2007: xiv). He has less to say about the religious nature of her work, other than to suggest that her Christian belief and espousal of Xhosa tradition produced a radical self-division or alienation (he refers to her as a "torn Christian", a "stranger in town" $(1998: 195,208))$ - a reading which I think is erroneous - and to comment that her poetry is "refreshingly - and sadly - modern" (2007: xxxvi), apparently both in terms of the nature of its address to urban dislocations, and its abandonment or modification of traditional Xhosa poetic structures.

Besides my own work and that of Opland, the other person to have written on Nontsizi Mgqwetho is, intriguingly, Thabo Mbeki. In his regular column in ANC Today he presents Mgqwetho as a pioneering Xhosa intellectual, especially concerned with unity and nation-building. Although the relevant section of the column is entitled “A Thunderous Woman's Voice”, Mbeki does not mention gender issues, but instead includes a poem which Mgqwetho produced about political division (the column appeared about two months before the 2007 Polokwane conference), and notes: "In rage, she spoke of responsible leadership, which should not use the masses of the people as sacrificial lambs.” Despite the biblical nature of his own phrasing (and, as West (2009) has shown, his own frequent use of the Bible in speeches), Mbeki makes no mention of Mgqwetho's Christian faith.

In contrast to this more secular/nationalist approach, and in view of her considerable interest in reading the Bible (of which more below), one might wish to approach Mgqwetho's work from the perspective of the growing field of postcolonial biblical scholarship. One of the pioneers of the field, Musa W Dube, outlines its concerns as follows:

Post-colonial readings of the Bible must seek to decolonize the biblical text, its interpretations, its readers, its institutions, as well as seeking ways of reading for liberating interdependence. Liberating interdependence here entails a twofold willingness on the part of readers: first to propound biblical readings that decolonize imperialistic tendencies and other oppressive narrative designs; second, to propound readings that seek to high-light the biblical texts and Jesus as undoubtedly important cultures, which are, nonetheless, not 'above all' but among the many important cultures of the world. (1998: 133) 
Kwok Pui-lan's exposition of a specifically postcolonial feminist interpretation of the Bible might also provide a model: "A postcolonial feminist interpretation of the Bible needs to investigate the deployment of gender in the narration of identity, the negotiation of power differentials between the colonizers and the colonized, and the reinforcement of patriarchal control over spheres where these élites could exercise control" (2005: 9). She refers to "[t]wo exciting books that have come out in recent years [which] demonstrate the complex and multiaxial reading strategies such an interpretation requires" (2005: 9) - Gale Yee's Poor Banished Children of Eve: Women as Evil in the Hebrew Bible (2003) and Dube's own Postcolonial Feminist Interpretation of the Bible (2000).

The problems with these approaches for me, and their limitations in finding a more adequate way of reading someone like Mqwetho, lie in the apparent assumptions that such readings must be authored (at least initially) by postcolonial theologians, rather than ordinary readers: such studies indicate what postcolonial subjects should be doing, rather than what they are doing. In fact, postcolonial/feminist biblical readings may be substantially at odds with readings 'on the ground': someone like Mgqwetho, and I suspect many African Christians today, would probably disagree strongly with Dube's assertion that "the biblical texts and Jesus" are "not 'above all'”, but simply "among the many important cultures of the world" - an assertion which speaks of religious pluralism (rather than religious tolerance, which I suspect they would support). While the need for such directed and prescriptive rereading strategies may be understandable given the implication of Christianity and biblical discourse in apartheid, colonial and patriarchal histories, I would like to explore more carefully what 'postcolonial' readings people may already be, or have been, undertaking: reading an 'organic theologian', to twist Gramsci's phrase, who has a strong - often strikingly assured - sense of her own agency. Emic, rather than etic, readings have considerable interest for me in considering religion, spirituality and the postcolonial, and suggest potentially richer modes of interpretation, at least in the first instance. ${ }^{6}$ This is not to deny historical or denominational influence on someone like Mgqwetho for, as we shall see, missionaries and mission discourse inform, though they do not determine, her theology.

$$
* * *
$$

Terence Ranger says, "any scholar who aspires today to 'think in black' about many of the people in eastern Zimbabwe has to learn also to think 
Methodist" (1994: 309). While I do explore the specific influence of Methodism below, I would extend that provocative statement further by saying that any scholar who aspires to 'think in black' about the African (sub)continent has to learn also to think biblically. The Bible is for many African Christians the foundational text of Africanness - an intratext of self definition, rather than intertext of cross-cultural encounter.

For African Christians like Mgqwetho the Bible - as opposed to the white man's Bible of the missionaries, which she regards as heretical ${ }^{7}$ provides a mode of being ethically and assertively African, especially in response to colonial depredation and social destruction. When she says in an early poem:

If you would return to Jehovah with all your heart,

cast out from among you

all foreign gods.

1 Samuel 7:3(32)

she is clearly assuming Jehovah to be African, and she characterises such “foreign gods" as money, alcohol and sexual immorality - the 'idols' of Western capitalism and colonial occupation.

A clear influence in Mqgwetho's assertion of an indigenised African Christianity is Methodism generally, and the African Methodist Episcopalian Church (AMEC) in particular. The Wesleyans and Methodism are mentioned in various poems, ${ }^{8}$ and the editor, Marshall Maxeke, of the newspaper Umteteli wa Bantu in which she published, and his wife, Charlotte, were both high-profile figures within the AMEC. Mgqwetho seems to have had a close relationship with the Maxekes, and writes of them approvingly in a number of poems, including describing Umteteli wa Bantu as having divine sanction (26). The couple met in the United States while Marshall was studying to become an AME missionary. With its own roots in the African-American anti-slavery movement, and the formal incorporation of the Ethiopian church in South Africa into the AME fold in 1896 (Campbell 1998: 103), the AME and Methodism provided an oppositional - if often accommodationist rather than radical - tradition to that of white mission societies, which became increasingly conservative in their alliances with colonial politics and economics. Terence Ranger (1994) and James T Campbell (1998) have written extensively on the AMEC in southern Africa, and their work is suggestive in reading Nontsizi Mgqwetho's poetry. 
A key theme within the AMEC doctrine was the consonance between 'traditional' or 'tribal' modes of life and Christianity. Mgqwetho affirms:

My people, there's pain in the truth:

this regime controls our lives today.

It thrashed us through trust in the scriptures, saying "Lay your blankets aside!”

...

The truth must be treated fairly,

the truth must be heard by both sides:

the truth is there in the scriptures

and also within our blankets. (196)

At an annual AME conference in eastern Zimbabwe some thirty years later, the newly-appointed African archivist spoke analogously of the church's commitment to both Bible and blanket: "Since we should be proud of our church and our tribal history - the cornerstone of our character and behaviour - I want to lay greater emphasis on the importance of our people learning the worthwhile teachings of our Church and of our tribal life and putting them into practice" (Ranger 1994: 281-2; italics in original). The AMEC also placed considerable emphasis on the economic well-being of its congregants, preaching the 'Gospel of the Plough', and seeking to develop a prosperous peasantry, rather than leaving its members as impoverished labourers or migrant workers (287-8). Mgqwetho herself identifies the economics of subordination employed by colonial and mission administration:

Our ignorance crushes us.

My people, we mustn't sell our maize,

we'll just be forced to buy it back.

...

Bright as pennies we all drink tea

and trade our maize for sugar.

...

When we sell our maize, we sell it cheap;

when we buy it, the white hikes the price. (118-20)

She also refers to the related need to buy land: "We'd do well to buy land:/ black nations must act together" (88). In particular, the AMEC was concerned with the social and economic plight of African women as "the most oppressed part of an oppressed race, enslaved or bartered and crushed by unremitting physical labour" (Ranger 1994: 289), and formed women's prayer unions, the manyano, which feature prominently in 
Mgqwetho's own poems. AMEC preachers were also encouraged to use vernacular forms and oral techniques, as well as 'indigenous' images such as cooking porridge or bridewealth (302-3), as evident in the African 'parables' told by someone like James Chikuse: “The caterpillar leaves his coat on a tree. He does not go back for it. It should be so when we leave our sins with Jesus” (302). Such oral techniques and African proverbial allusions are widespread in Mgqwetho's work.

One could certainly read Mgqwetho as a talented, if representative, African Methodist woman of the early twentieth century, negotiating the complexities of life on the Witwatersrand with the discourses at her disposal, and I think that line of enquiry could yield fruit. But Mgqwetho's work seems to exceed such an approach: with extraordinary authority she reads the Bible against its 'misreadings'; her prophetic voice seems to range backward and forward in time, speaking eloquently to concerns that strike a chord even in contemporary South Africa. Her poems - as poems - spill beyond the confines of context and denomination.

Mgqwetho is emphatic that 'the Bible' is a reading, rather than a book (and there had been various Xhosa translations of the Bible). Her own reading of the Bible is set against those of the missionaries: readings which are perceived to be oppressive and blasphemous. She says, for example, “The hypocritical cant of the white man's gospel/ turns Phalo's land on its head" (160), "The simple truth is they came to oppress,/ they came to blaspheme with their bible" (230), and "When the white appeared, all was normal:/ abnormality came with his bible" (278). In contrast, she seeks in her reading a new, true, Bible: "The bible was written by prophets:/ modern prophets, produce a new bible” (84). In this new Bible, the biblical texts are re-membered - to use Gerald West's phrase (1999: 95-6) - they are reauthored; the new Bible authorises her and her fellows, granting both 'authority' and 'authorship'.

There was, and still is, certainly a strong emphasis on reading the Bible within the AMEC and Methodism generally, and Ranger points out that reading the Word is often central to testimonies of AME conversion (1994: 285). However Mgqwetho's Bible reading extends far beyond such denominational requisites. She refers in her poems implicitly or explicitly to 30 of the 66 books of the Bible, including some like Song of Songs which are less well known, ranging from Genesis to Revelation, and including Deuteronomy, Job, the prophets, the psalms, the gospels, and especially the Pauline letters. She assumes in her audience considerable 
familiarity with the Bible. To take just one example, in a poem dealing with animosity between two women's groups, Mgqwetho invokes the "dews of Hermon/ watering Zion's hills” (162). The reference is to Psalm 133:3, though this is not stated in the poem, and the logic of Mgqwetho's argument depends on one's knowing the connotations of the image in the psalm (the psalm is about filial love).

Her biblical authoring or re-authoring ranges from the subtle to the explicit. In a poem about the evils of alcohol, she refers to "Solomon's proverbs in Chapter 22". In fact that chapter in the book of Proverbs does not mention alcohol or drunkenness, but its general tenor of self-control is appropriate. Mgqwetho thus implicitly draws Solomon into her temperance argument. More dramatically, she literally re-authors or remembers (and translates) the Bible for a (South) African context in the prose introduction to a poem which draws on the image of the writing on the wall from Daniel 5:25 (and again the title and first line of the poem assume on the part of the readers a thorough knowledge of the Bible):

Mene! Mene! Tekel! Parsin!!

Daniel 5:25

That, my people, is the writing on the walls of the nation. It is written in Hebrew. The translation reads: "God has made a complete accounting of your kingdom. You have been weighed on the scale and found wanting. Your kingdom is therefore confiscated and handed to the nations on our borders." Now this seems to refer to you and to me. Take the fourth verse of the same chapter. It reads: "We drank wine and praised foreign gods of gold and silver, brass and iron, wood and stone.” Isn't that true? Look at the great variety of fripperies in this country. Reader, take note. Would that same hand that wrote on those walls over there not write today on the walls of Africa? Take again verse 23 in the same chapter. It reads: "We exalted ourselves above God in heaven." Today we considered our customs Red, thus making God a Red, He who holds in His hands our breath and our every path. Peace! (200)

God is 'made Red' in the textuality of the prose introduction to poem 88, which improvises in the interactive style of the AMEC sermon or manyano preaching:

Will the judge return? Yes! He says he is going to prepare a place for us (John 14:2; Hebrews 11:16; Galatians 4:26; Hebrews 11:10). Who among the prophets bears witness for Jesus that he saw this place? John (Revelation 21:2). Are we all permitted to go to that village? No! Why not? Aren't all of us who go to prayers every Sunday Christians? No! 
Only those who heed his instructions (Revelation 22:14). Furthermore, those who do will see God face to face: consult Revelation 22:2-4; Matthew 5:8; Hebrews 12:14; Corinthians 13:12. May he who prepared a place for us in heaven be praised: Ephesians 1:3. (384)

The poem entitled in Opland's translation "Why was the Bible Created?" uses as its text Romans 15:4. Mgqwetho's voice segues with that of Paul, without the use of quotation marks, into a discourse on the late eighteenthand early nineteenth-century Xhosa prophet Ntsikana:

For whatever was written in former days was written for our instruction, that by patience and by the encouragement of the scripture we might have hope. Now listen! Didn’t Ntsikana tell you to study the scriptures? And you left the whites to study them for you. I'm not mocking the white when I say that. But when it's written "Seek and ye shall find," it doesn't mean that someone else must do the finding. Listen then. (420)

Ntsikana is invoked by Mgqwetho in relation to prophecy, and her own voice is powerfully prophetic. In a poem produced towards the end of 1924, Mgqwetho links Ntsikana with Isaiah, and the two prophets seem to hold the same status (as does she, perhaps, by the authority of her Bible reading and poem?):

What does the prophet Isaiah say?

When you've done trampling, you'll be trampled.

Why can't you see what I've seen for so long?

Didn't Ntsikana tell you?(242)

Similarly, in the prose introduction to a poem produced a little later, Mgqwetho invokes Isaiah 19:18, and then allows her own discourse to flow directly on from Isaiah's, again via Ntsikana:

We just don't have time to fumble in the fog: consult Isaiah 19:18.

On that day, five of the houses of the land of Egypt will speak in the Canaanite language and swear only by Jehovah of the hosts. And Canaan is the home of blacks everywhere. There is no Jehovah of Ntsikana alone or of the Mfengu alone. Oh, no! There is only the Jehovah of all the black nations under the sun, united, commemorating the same thing and crying as one: so clap your hands! (300).

Ntsikana was perceived by many to be the first "to be a Christian while remaining an African” (Mills 1997: 342-3). This alliance between Isaiah's, Ntsikana's and Mgqwetho's prophetic modes suggests that this is a specifically African-Christian voice. The prophetic is a return, a call to turn 
back from the wrong path, a looking backwards as much as forwards; it is retrospective, but with a clear present and future orientation. Es'kia Mphahlele describes prophecy in a distinctively African way, which is appropriate to Mgqwetho and Ntisikana (and Isaiah?): a prophet is someone "who sings, the prophet sings, and in what [s/]he sings [s/]he repeats a number of things ... I am using the word 'sing' in the widest possible sense. When you sing you repeat a number of notes. Just like the blues. As you sing, it echoes and goes forward and back again over what you have said before. A prophet does that" (quoted in Raditlhalo 2007: 268-9). In this model, prophecy is an improvisation on a series of notes, which closely matches the textual model of izibongo, itself a powerfully prophetic form. It seems that Mgqwetho, like Ntsikana in his "Great Hymn”, finds a significant congruence between the indigenous forms of praise poetry and the prophetic model of the Bible (one could describe the prophetic voices of Daniel, Isaiah or Ezekiel as playing in different ways over the 'same' series of notes). While her poems are clearly influenced by the hymnal tradition, with the use of regular verse/stanzaic structure, they are at heart praise poems. Scheub talks of the way in which the form of izibongo establishes a 'grid' on which images and symbols are constantly realigned, and experienced in new relationships (1987: 485); improvisation happening within a set of 'common' images. The twentiethcentury African Christian prophet, Nontsizi Mgqwetho, speaks as an imbongi through the modern medium of the newspaper, and her poems - which disappear when the paper is discarded, as the oral performance would exist only in the moment of its utterance - are, as Coplan says of praise poetry generally, "elaborations upon a mutually resonant set of master metaphors ... ordered according to an emotional and aesthetic logic of incremental effect” (1987: 12).

The praise poet is a liminal figure, one who speaks to the present from the perspective of past and future. He (or she in this case) is concerned with maintaining social cohesion and stability, but produces poems from a sense of inner compulsion, identified by Mphahlele as the catalyst for prophecy:

Now before you can become a prophet, you have got to be discontented. No person gets up in the morning one day and decides to prophesy, just like that, without feeling a kind of ecstasy or rage - without a sense of compulsion. You have got to be driven by an inner compulsion. (Quoted in Raditlhalo 2007: 268-9)

That 'inner compulsion' involves, for people like Mgqwetho, a sense of living temporally and atemporally (to use the terms Peel suggests are 
involved in religious experience generally (2003:5)); of accessing spiritual power which speaks into but also beyond the temporal and the earthly.

In finding an answer to the question of how we might approach Mgqwetho, I have tried to take seriously her African Christian belief, to give credence to her biblical understanding, and to read through the textures and timbres of her poetic and prophetic address. In doing so, I find myself encountering a voice which speaks beyond history and into it; and one which offers an insistent address to present circumstances. Perhaps more than simply being politically opportunist, Thabo Mbeki was responding to the prophetic nature of Mgqwetho's poetry in quoting her censure of political selfinterest in the run-up to Polokwane. I referred earlier, somewhat critically, to Opland's judgement that Mgqwetho's poetry was “refreshingly - and sadly - modern". As regards the prophetic nature of her African Christian address, perhaps his comment is apposite. Lines like the following, written in 1924, have an extraordinary resonance in South Africa today:

Take the African National Congress:

we once burst our ribs in its praise.

Now we go round in search of it:

"Has anyone seen where it’s gone?"

None can deny, I'm sorry to say, these questions have some point.

But as for me, I'm not at pains

to mock their efforts to date.

Vying for status is lethal poison

internally sapping Congress. (94)

\section{Notes}

1. My thanks to Michael Green for directing me to Mantel's article.

2. See Opland (1997; 2007), and Brown (2006). I am extremely grateful to Opland for providing me with access to the manuscript in which he had collected and translated the poems, prior to its publication.

3. I have discussed Opland's translation strategy elsewhere (Brown 2006).

4. From this point onwards, Mgqwetho's poems and articles will be referenced by page number only.

5. The biographical information which follows has been gleaned from Opland's biographical summary (2007), as well as from my own close readings of the poems and articles.

6. I am grateful to Gerald West for discussing this issue with me. Dube has herself 
argued elsewhere for the significance of 'reading with' (1996), an approach closer to that which I investigate here than the more directed reading strategies she outlines in her contribution to the edited volume The Postcolonial Bible (1998). See the Special Issue of Semeia, on "Reading With: African Overtures", edited by West and Dube (1996).

7. I have discussed this at length elsewhere (see Brown 2006: 37-77).

8. See especially poems 31 and 56 .

\section{References}

Brown, Duncan. 2006. To Speak of this Land: Identity and Belonging in South Africa and Beyond. Pietermaritzburg: University of KwaZuluNatal Press.

Campbell, James T. 1998. Songs of Zion: The African Methodist Episcopal Church in the United States and South Africa. Chapel Hill and London: University of North Carolina Press.

Coplan, David B. 1987. "Dialectics of Tradition in South African Popular Theatre". Critical Arts 4(3): 5-27.

Daymond, M J et al (eds). 2003. Women Writing Africa: The Southern Region. Johannesburg: Witwatersrand University Press.

Dube, Musa W. 1996. "Readings of Semoya: Batswana Women's Interpretations of Matt. 15:21-28”. Semeia 73. Special Issue on “'Reading With”: African Overtures”: 111-29.

1998. "Saviour of the World but not of this World: A PostColonial reading of Spatial Construction in John”. In: R S Sugirtharajah (ed). The Postcolonial Bible. Sheffield: Sheffield Academic Press: 118-35.

2000. Postcolonial Feminist Interpretation of the Bible. St Louis: Chalice Press.

Gaitskell, Deborah. 1997. "Power in Prayer and Service: Women's Christian Organisations”. In: Richard Elphick and Rodney Davenport (eds). Christianity in South Africa: A Political, Social and Cultural History. Oxford: James Currey; Cape Town: David Philip: 253-67.

Hofmeyr, Isabel. $\quad$ 2004. The Portable Bunyan: A Transnational History of The Pilgrim's Progress. Princeton and Oxford: Princeton University Press.

Kwok Pui-lan. 2005. Postcolonial Imagination and Feminist Theology. London: SCM Press. 
Mantel, Hilary. $\quad$ 2004. “Some Girls Want Out”. London Review of Books, 4 March: 14-18.

Mbeki, Thabo. 2007. “Letter from the President”. ANC Today 7(38) 28/9-4/ 10. http://www.anc.org.za/ancdocs/anctoday/2007/text/ at38.txt. Accessed 1/5/2008.

Mills, Wallace G. $\quad$ 1997. "Millennial Christianity, British Imperialism and the Social Gospel”. In: Richard Elphick and Rodney Davenport (eds). Christianity in South Africa: A Political, Social and Cultural History. Oxford: James Currey; Cape Town: David Philip: 337-46.

Opland, Jeff. $\quad$ 1997. “The Drumbeat of the Cross: Christianity and Literature”. In: Richard Elphick and Rodney Davenport (eds). Christianity in South Africa: A Political, Social and Cultural History. Oxford: James Currey; Cape Town: David Philip: 297-318.

1998. Xhosa Poets and Poetry. Cape Town: David Philip. (ed and transl). 2007. The Nation's Bounty: The Xhosa Poetry of Nontsizi Mgqwetho. Johannesburg: Witwatersrand University Press.

Peel, J D Y. $\quad$ 2003. Religious Encounter and the Making of the Yoruba. Bloomington and Indianapolis: Indiana University Press.

Raditlhalo, Sam Tlhalo. 2007. “Assembling the Broken Gourds: An Appreciation”. In: Njabulo S Ndebele. Fine Lines from the Box: Further Thoughts about our Country. Cape Town: Umuzi.

Ranger, Terence O. 1994. "Protestant Missions in Africa: The Dialectic of Conversion in the American Methodist Episcopal Church in Eastern Zimbabwe, 1900-1950”. In: Thomas D Blakely et al (eds). Religion in Africa. London: James Currey; Portsmouth: Heinemann: 275-313.

Scheub, Harold. $\quad$ 1987. “Oral Poetry and History”. New Literary History 18(3): 477-96.

West, Gerald O. $\quad$ 1996. "Reading the Bible Differently: Giving Shape to the Discourse of the Dominated”. Semeia 73. Special Issue on “'Reading With': African Overtures”: 21-41.

1999. The Academy of the Poor: Towards a Dialogic Reading of the Bible. Sheffield: Sheffield Academic Press.

2009. “Thabo Mbeki’s Bible: The Role of Religion in the 
South African Public Realm after Liberation”. In: Duncan Brown (ed.). Religion and Spirituality in South Africa: A Postcolonial Perspective. Pietermaritzburg: University of KwaZulu-Natal Press. (Forthcoming)

West, Gerald O and Musa W Dube (eds). 1996. Semeia 73. Special Issue on “'Reading With': African Overtures”.

Yee, Gale. 2003. Poor Banished Children of Eve: Women as Evil in the Hebrew Bible. Minneapolis: Fortress Press. 